\title{
ЗАСТОСУВАННЯ ПЕДАГОГІЧНИХ ПРОГРАМНИХ ЗАСОБІВ ОСВІТИ В НАВЧАЛЬНОМУ ПРОЦЕСІ ВИЩОЇ ШКОЛИ
}

\author{
Л. Б. Муц \\ ДВНЗ “Тернопільський державний медичний університет імені І. Я. Горбачевського МОЗ України”
USE OF PEDAGOGICAL SOFTWARE OF EDUCATION IN EDUCATIONAL PROCESS OF HIGH OF SCHOOL \\ L. B. Muts \\ SHEI "Ternopil State Medical University by I. Ya. Horbachevsky of MPH of Ukraine”
}

\begin{abstract}
Обгрунтовано необхідність застосування педагогічних програмних засобів навчання в навчальному процесі вищої школи. Визначено їх практичну значущість в умовах кардинальних змін сучасної освіти. Розкрито зміст і методологію створення педагогічних програмних засобів навчання та алгоритми їх застосування. Розглянуто вимоги для розроблення педагогічних програмних засобів і критеріїв їх оцінювання. Проаналізовано результати експериментального впровадження даних засобів навчання в навчальний процес.
\end{abstract}

The article adduces the necessity to use pedagogical software of education in the educational process of high school. It was determined their practical significance in terms of radical changes of modern education. The content and methodology of pedagogical educational software and learning algorithms for their application were adduced. There were considered requirements for the development of pedagogical educational software and criteria of their evaluation. Results of experimental implementation of training data in the learning process were analyzed.

Вступ. Реформування освіти в Україні зумовило корінні зміни у навчальному процесі середньої та вищої школи. Вищі навчальні заклади України впроваджують нові технології навчання, популярними серед яких $€$ комп'ютерне та дистанційне навчання, методи проектів, інтерактивні методики.

Основна частина. Педагогічну технологію можна розглядати як впорядковану систему дій, виконання яких приводить до досягнення поставленої мети, або як системний метод створення, впровадження i визначення цілого процесу викладання і засвоєння знань з урахуванням технічних і людських ресурсів (ЮНЕСКО). Отже, педагогічна технологія функціонує і як наука, що досліджує раціональні шляхи навчання, і як система способів, принципів і регуляторів, які застосовуються у навчанні, i як реальний процес навчання.

Вченими виокремлено такі види технологій навчання: -інформаційні (формування знань, умінь, навичок);

- операційні (формування способів розумових дій);

- емоційно-художні й емоційно-моральні (формування сфери естетичних і моральних відносин);

- технології саморозвитку (формування самоуправляючих механізмів особистості);

- евристичні (розвиток творчих здібностей);
- прикладні технології (формування дієво-практичної сфери) [1].

Відповідно до визначення, яке було прийняте ЮНЕСКО, інформаційна технологія - це комплекс взаємозалежних, наукових, технологічних, інженерних дисциплін, що вивчають методи ефективної організації праці людей, зайнятих обробкою і збереженням інформації; обчислювальну техніку і методи організації і взаємодії з людьми і виробничим устаткуванням, їхні практичні додатки, а також зв'язані з усім цим соціальні, економічні і культурні проблеми.

Самі інформаційні технології вимагають складної підготовки фахівців, великих первісних витрат і наукомісткої техніки. Їхнє введення повинно починатися зі створення програмного забезпечення, програмних засобів навчання, формування інформаційних потоків у системах підготовки спеціалістів [1].

Світовим лідером у виробництві програмного забезпечення i, зокрема, програмних засобів навчання $\epsilon$ корпорація Microsoft (США).

Педагогічним програмним засобом $є$ такий засіб, у якому відображено деяку предметну галузь, повною мірою реалізовано технологію іiі вивчення, забезпечено умови для здійснення різних видів навчальної діяльності [2].

\section{(ㄱ Л. Б. Муц}


За допомогою програмних засобів можна подати на екрані у різній формі навчальну інформацію; ініціювати процеси засвоєння знань, набуття умінь та навичок навчальної або практичної діяльності; ефективно здійснювати контроль за результатами навчання, тренування, повторення та аналіз вивченого матеріалу, розвиток пізнавальної діяльності [7].

Проблемі вивчення педагогічних програмних засобів і критеріїв їх оцінювання присвячена значна кількість наукових досліджень вітчизняних і зарубіжних вчених, зокрема: А. А. Кузнецова, М. І. Жалдак, I. В. Роберт, В. М. Дем'яненка, Н. В. Морзе, М. П. Шишкіної та інших.

Більшість програмних засобів, що вже існує на ринку України, являють собою електронні версії друкованих підручників і посібників для загальноосвітніх шкіл. Останнім часом з'являються педагогічні програмні засоби, в яких увага сконцентрована не лише на інформаційному наповненні, але й на забезпеченні взаємодії користувача з програмою та роботи у діалоговому режимі. Сучасні педагогічні програмні засоби навчання дозволяють користувачеві самостійно моделювати різні процеси, проводити досліди та здійснювати контроль засвоєного матеріалу за допомогою тестування. Так, наприклад, електронні атласи окрім карт мають тексти, що коментують і доповнюють інформацію, подану на картах, запитання для самоперевірки, ілюстрації і навіть ігри на основі карт атласів. Багато підручників з фізики та хімії дозволяють окрім вивчення матеріалів курсу проводити лабораторні роботи, демонстрації, досліди та тестування. Мовні програми також мають режими навчання, практики та тестування. Біологічні підручники мають у своєму складі окрім текстів ілюстрації рухомі моделі об'єктів, тестові завдання. Математичні підручники дозволяють створення та розв'язування рівнянь і задач, побудову графіків. Електронні підручники з інформатики містять навчальні та довідникові посібники, середовища програмування та демонстрації. Отже, можна зробити висновок про багатоплановість та різноманітність можливостей сучасних педагогічних програмних засобів навчання [3]. Однак для вищої школи таких ППЗ на сьогодні обмаль.

Дослідження з педагогіки і педагогічної психології свідчать про те, що доцільно надати розробці ППЗ трьохетапного характеру.

На першому етапі створюється головний педагогічний робочий документ - сценарій для комп'ютерного навчання. Це може бути сценарій заняття, розділу програми, навчального предмета в цілому. В сценарії формулюють мету, зміст, методи та організаційні форми навчання, прийоми управління навчальною діяльністю.

На другому етапі складання програми слід повною мірою врахувати дидактичні принципи навчання.

На третьому етапі рекомендовано детально вивчити нормативну навчальну програму з певної дисципліни, комплект навчальної документації $з$ професії, знайти та закласти у сценарій внутрішньопредметні та міжпредметні зв'язки [7].

Аналіз тенденцій розвитку ринку ППЗ, з точки зору реального впровадження в освітню практику, показує, що цей процес проходить достатньо повільно. Обмеженість попиту на ППЗ на відкритому ринку не забезпечує окупність продукту, підвищує відносну вартість розробки ППЗ, що гальмує розвиток ринку цих засобів, а як наслідок, і їх впровадження в освітню практику. На погляд багатьох вчених, такий стан справ має як об'єктивні, так і суб'єктивні причини. Розглянемо детальніше деякі з них.

1. У процесі створення конкретного ППЗ, тобто в процесі визначення його структури, змісту, форм і способів представлення в ньому навчальної інформації, забезпечення рівня можливості інтерактивної взаємодії в системі студент - комп'ютер та багато іншого, що характерно для зазначених засобів, автори-розробники виходять з суб'єктивного розуміння цілей $i$ методів навчання, свого особистого педагогічного, проектного та виробничого досвіду, тих теоретичних положень і концепцій, які розуміють і поділяють, власних естетичних уподобань [5]. Хоча все вищеперераховане $€$ певним узагальненням суспільної практики, досвіду. ППЗ тією чи іншою мірою відображає риси домінуючої сьогодні освітньої парадигми, але обмежені тією конкретною предметною галуззю, представниками якої є автори конкретного засобу.

2. Кожен ППЗ, як і традиційний засіб, наприклад друкований підручник, посібник тощо, $є$ результатом творчості авторів, внаслідок чого має власні неповторні якості, власну структуру, оформлення, естетику, функціональні можливості, зміст, способи і форми подання навчальної інформації тощо. Результатом різноманітності підходів, строкатості спектра авторських задумок та методів їх реалізації $є$ різноманітність підходів до способів використання комп'ютерно орієнтованих засобів навчальної діяльності в навчально-виховному процесі [6].

3. Якщо розглядати ППЗ як засіб, що пропонує користувачу певний набірпослуг, використання яких розширює спектр навчальної діяльності, збагачує навчально-виховний процес, змінює структуру навчального середовища, тоді етап опанування сервісними 
можливостями засобу набуває першочергового значення. Аналізуючи ринок ППЗ, можна зробити висновки, що їх різноманітність навіть на рівні організації інтерфейсу, тобто розташування інформації на екрані, його кольорового насичення, змістовного наповнення, організації управління екранною подією, відео- та аудіосупроводженням навчального матеріалу викликає необхідність витрачати значну частку навчального часу на опанування користувачами способів управління засобом [8, 9]. 3 педагогічної точки зору в цьому випадку саме навчальна інформація відходить на другий план, стає фоновою, а навчальним завданням стає опанування засобом, набуття навичок безпомилкового використання засобу. Безумовно, це сприяє підвищенню “комп’ютерної грамотності” підростаючого покоління, але освіта не обмежується тільки такою грамотністю.

4. 3 позиції вчителя (викладача), відсутність системного підходу до забезпечення навчального процесу конкретними ППЗ ускладнює визначення "точки входження" цих засобів у навчальний процес, адаптування авторських поглядів розробників до тих поглядів на структуру, мету, організацію навчальновиховного процесу, тих методик використання різного типу засобів навчання, які властиві конкретному викладачеві. Наприклад, характерним для білышості класифікацій ППЗ є експертний підхід до визначення системоутворюючих факторів, за якими автори типізують ці засоби [10].

Для викладача, який формує систему засобів, зокрема ППЗ, для їх використання у власній професійній діяльності, повинна існувати проблемно-орієнтована класифікація, що враховує, зокрема, такі експеримен- тально визначені характеристики, як:

- рівень спрямованості на досягнення педагогічної мети (в різних педагогічних ситуаціях);

- характеристику важкості опанування сервісними можливостями;

- час, який потрібен різним категоріям користувачів на опанування засобом;

- комплекс методик, які дозволяють педагогічнораціонально використовувати даний конкретний засіб тощо [4].

Висновок. На нашу думку, введення ППЗ в навчальний процес вищої школи може підвищити ефективність навчання, оскільки всі необхідні матеріали для підготовки до практичних та семінарських занять певної дисципліни систематизовані по темах на одному web-сайті. Крім того, кожна тема поділена на певні розділи, наприклад: методичні вказівки до виконання практичних занять, орієнтовний план семінарського заняття, основна література, додаткова література, глосарій, відео- та медіаматеріали, табличний фонд, контроль знань, посилання на корисні web-сайти, зворотний зв'язок, форум для студентів. Дуже важливо для навчання студентів зворотний зв'язок з викладачем, оскільки у студента може виникати низка питань, які потрібно пояснити викладачеві. Таким чином викладач виступає як консультант для студента, який скеровує його освітню діяльність в правильне русло, корегує та виправляє неточності. Даний web-сайт повинен постійно оновлюватися і корегуватися. Це сприятиме підвищенню рівня кваліфікації педагога.

Використання ППЗ в навчальному процесі допоможе перейти на новий рівень освіти, пришвидшить процес створення єдиного освітнього простору.

Р. С. Гуревич, М. Ю. Кадемія. - К. : Освіта України, 2006. 383 c.

8. Жук Ю. О. Вплив ІКТ на формування особистості школярів/ Ю. О. Жук// Інформатика. -2003. -№9 (201).-С. 3-5.

9. Жук Ю. О. Характерні особливості поведінки у комп’ютерно орієнтованому навчальному середовищі / Ю. О. Жук // Комп'ютерно орієнтовані системи навчання : зб. наук. праць. -К. : НПУ ім. М. П. Драгоманова, 2001.-Вип. 4.

10. Основи нових інформаційних технологій навчання : посібник для вчителів / авт. кол. ; за ред. Ю. І. Машбиця / Інститут психології ім. Г. С. Костюка АПН України. - К. : I3МН, 1997.-264 c.

11. Сумський В. І. ЕОМ при вивченні фізики : навч. посіб. / В. І. Сумський. -К. : НМЦ “Укоопосвіта”, 1999. - 357 с. 